\title{
Biodiversity, Conservation and Development in Asia: how Protected Areas can Contribute to Local Communities
}

\author{
JEFFREY A. McNEELY \\ Chief. Biodiversity Officer IUCN 1196 Gland, Switzerland \\ (Received september 16. 1993)
}

INTRODUCTION

Many countries around the world have found that protected areas play an important role in sustainable development, conserving biodiversity, and providing numerous benefits to society. Over 8000 such areas exist. covering some $5 \%$ of the land surface of the earth. It is clear that protected areas cannot coexist with communities which are hostile to them. But when protected areas are designed and managed effectively, they can make important contributions to human welfare and earn broad public support (MacKinnon, et al., 1986). Drawing upon information presented at a recent congress on national parks and protected areas (McNeely, 1993), this paper examines the central issue in establishing successful protected areas: that is. how protected areas can be managed in ways that provide benefits to local people, without detracting from the natural values for which the areas were established.

Before answering this operational question, two more fundamental issues need to be considered: (a) what it menas "to conserve nature" in the modern context: and (b) what "protected areas" are and how they contribute to human welfare.

\section{Nature and rural communities in Asia}

The view of nature conservation which has tended to dominate international thinking over the past century sees humans as intruders into nature, valuing "pristine nature" as the ideal to the retained. However, humans have occupied Asia for several hundred thousand years, planying an important role in forming the ecosystems that are today considered "natural". The region saw some of the earliest domestication of plants and animals, some of the earliest cities, and some of the earliest irrigation. Many protected areas surround the ruins of these ancient civilizations; Angkor Wat is only the most famous example, but archeological sites are to be found in most of the portected areas of the region.

It has been pointed out that many of the tree species now dominant in the mature vegetation of tropical areas were, and still are, the same speices protected, spared, or planted in the land cleared for crops as part of the practice of shifting agriculture (Gomez-Pompa, et al., 1992). Furthermore, 
virtually all of the forests of mainland southeast Asia have been cleared at least once and probably several times over the past 10000 years (Spencer, 1966), and the temperate forests are likely to have been similarly treated (at least in areas accessible to people). As a result, the current pattern of Asian habitats reflects complex interactions among physical, biological, and social forces over time. The resulting landscape is an ever-changing mosaic of unmanaged and managed patches of habitat, which vary in size, shape, and arrangement owing to the heritage of cultivated fields and managed forests abandoned decades or hundreds of years age.

Whereas human activity can certainly deplete ecosystems, as can be observed by the wide expanses of wasteland found in many countries, the influence of local people can sometimes increase biodiversity rather than deplete it. For example, a comparison of two oases in the Sonoran Desert on either side of the Mexico-United States border indicated that the customary land-use practices of Papago farmers on the Mexican side of border contributed to the biodiversity of the oases (Nabhan et al. . 1982 ). In turn, the protection from land use of an oasis 54 kilometers to the northwest, within the United States Organ Pipe Cactus National Monument, resulted in a decline in the species diveristy over a 25-year period. In Tropical Asia, the continuation of a certain amount of shifting cultivation may be essential to the welfare of the large mammals of the region, such as kouprey (Bos sauveli), banteng (B. javanicus), gaur (B. gaurus), elephant (Elephas maximus), and tiger (Panthera tigris) (Wharton, 1968).

Indigenous human groups have survived because they have used their resources sustainably. But this behavior should not be idealized. It was adaptive under conditions of low population density, abundant land, and limited involvement with a market economy. But techniques developed to satisfy subsistence needs are unlikely to work when surpluses are needed for cash. When confronted with market pressures, higher population densities, and increased expectations, the people living in remote areas will certainly seek more intensive ways to manage their resources (Redford, 1990).

The issue is not simply the presence or density of humans, but the tools, technologies, techniques. knowledge, and experience that accompany the relationship of a given society with the environment. In Asia, rural people are part of nature and have always seen themselves as such (McNeely, et al., 1991). Effective protected areas should not separate people from nature. but rather provide the conditions that will enable the continuing evolution of a healthy relationship between people and the rest of nature.

\section{Protected areas: different approaches to meet different community needs}

A protected area is a geographically defined area managed through legal or other effective means so as to protect and maintain biological diversity and natural and associated cultural resources (McNeely, 1992). As a result of the rather romantic Western view of nature mentioned above, some protected areas have been designed to exclude people. For example, the definition of IUCN of "national park" (Category II) calls for ecosystems "not materially altered by human exploitation and occupation" and expects governments "to prevent or eliminate as soon as possible exploitation or occupation in the whole area" (IUCN. 1990). 
This ideal is seldom attained, even in fairly wealthy countries. for example, it has been found that $86 \%$ of South American IUCN Category National Parks have permanent human occupation (Amend, et al. , 1992). It is apparent that governments are adapting the ideal to the reality of local conditions. For example, in India, rights of grazing, agriculture, and collection of forest products, such as fodder and firewood, are provided to local people in nearly half of the 52 national parks and in over two-thirds of the 209 sanctuaries (I PA, 1989), a compromise which may well be necessary to enable protected areas to make their larger contributions to society.

The previous discussion has suggested that while strict protection is often a necessary management objective, seeking to totally exclude human influence is a highly artificial measure which may be required in only relatively few protected areas. A more viable option, especially in the current social and economic climate in rural Asia, is a focus on sustainable use. For use to be sustainable in the long term, consumption cannot exceed the natural increment. In the short term, use should not exceed a level such that the stock of the resource falls below acceptable levels. What is acceptable is primarily a matter of judgement, based on reproductive rates, habitat condition, market demand, and other such parameters. But when the size of a stock is considered to have reached a level so low as to threaten the continued existence of the resource. then strict preservation may be the only available management strategy, requiring recovery before any harvest can again be contemplated.

Recognizing the need for a range of approaches to protected areas. from strict protection to sustainable use, IUCN has recently revised its system of protected area categories based on objectives for management (see below). Although national parks by definition need to be protected against human exploitation on a commercial scale, other categories of protected areas - such as species management areas, protected landscapes, and managed resource protected areas - can be established around the strictly protected areas to prevent them from becoming biologically impoverished islands, or can stand by themselves to make important contributions to systems of land management. Several of these categories of protected area can include sustainable utilization of resources as a management objective, to both conserve biological diversity and provide sustainable benefits to local human communities from the use of those resources. For example, IUCN Category VI can be used for protecting traditional forms of agriculture, as an integral part of a national protected-area system.

Table 1 Land use in East Asia

\begin{tabular}{l|c|c|c|c|c|c|c}
\hline & \multirow{2}{*}{$\begin{array}{c}\text { Cropland } \\
(\%)\end{array}$} & $\begin{array}{c}\text { Pasture } \\
(\%)\end{array}$ & $\begin{array}{c}\text { Forest } \\
(\%)\end{array}$ & $\begin{array}{c}\text { Other Land } \\
(\%)\end{array}$ & \multicolumn{4}{|c}{ Protected Areas $(\%)$} \\
\cline { 5 - 8 } China & 10.4 & 34.2 & 13.6 & 41.8 & 0.01 & 2.94 & 2.95 \\
Taiwan & & & & & 5.49 & 2.53 & 8.02 \\
Japan & 12.4 & 2.0 & 66.5 & 19.1 & 3.54 & 9.07 & 12.61 \\
Korea (DPR) & 16.5 & 1.4 & 74.7 & 8.3 & 0.36 & 0.11 & 0.47 \\
Korea (Rep.) & 21.6 & 0.9 & 65.8 & 11.7 & 0.42 & 7.27 & 7.69 \\
Mongolia & 0.9 & 79.0 & 8.9 & 11.2 & 3.94 & 0.00 & 3.94 \\
\hline
\end{tabular}

Improvements in conservation over the coming decades are likely to lie primarily in the 
establishment, implementation, and improved management of those categories of protected area where some human use will be tolerated or even encouraged, or on new types of protected area in degraded landscapes which have been restored to productive use for conservation. Strictly protected areas (Categories I and II) are unlikely to ever cover more than about $5 \%$ of a country. But since permanent agriculture covers only about $15 \%$ of the land area in East Asia (Table. 1), ample land exists for forestry, shifting cultivation. grazing, and other uses that may, with proper management. contribute to the conservation of biological diversity. Many such areas might surround the more strictly prtoected national parks, helping to buffer them against the more negative human influences.

Protected areas need to be part of broader regional approaches to land management. The term "bioregion" has been used to describe extensive areas of land and water that include protected areas and surrounding lands. preferably including complete watersheds (catchments), where all agencies and interested parties have agreed upon collaborative management (Grumbine. 1990). In order for the bioregion to be managed sustainably, it must include sufficient habitat to support viable populations of all native species in the region: areas large enough to accommodate natural disturbance regimes; a time line of centuries within which species and ecosystem structures and processes may evolve; and human occupancy and use at levels that do not result in ecological degradation. A bioregion is a convenient scale at which to integrate planning and management of various uses which have variable effects on biodiversity, yet is small enough to be mapped in detail and managed by people who know the land well (Grumbine, 1990).

The biosphere reserve approach, developed by UNESCO (Paris) and IUCN over the past 20 years, provides a valid expression of bioregional conservation (Batisse, 1986; Ishwaran, 1992). Ideally, biosphere reserves serve three functions: (a) conservation; (b) logistics (including research. monitoring of environmental parameters, training, and environmental education); and (c) the development of regions immediately adjacent to the reserve. They are sites where well-informed management carries out the logistic functions in order to demonstrate the linkages between conservation of biodiversity and the sustainable socioeconomic development of surrounding regions. Each biosphere reserve ideally consists of three concentric zones: a "core zone", a "buffer zone", and a "transition zone". The core zone comprises a minimally disturbed ecosystem that is clearly delineated and legally protected. The surrounding buffer zone is also clearly delineated and legally protected, but is managed to accommodate a greater variety of resource-use strategies than is permitted within the core. Management strategies for the buffer zone are designed with the long-term goal of minimizing the resource dependency of local people on the core. The outermost transition zone is an area where reserve management activity cooperates with the local people for promoting sustainable development.

In deciding which apporach is best for any particular situation, the responsible agencies will wish to keep in mind that indigenous knowledge. information, and techniques are clearly more relevant to the design of nature-protection policies, plans, and programmes than are the exogenous concepts and ideas that often characterize modern conservation. The participation of the local people in the formulation of nature policy and management decision making is therefore the key to sustainable programmes. Details on how to ensure this participation are presented below.

Although all protected areas control human occupancy or use of resources to some extent. 
considerable latitude is available in the degree of such control. Talbe 2 illustrates the system of six categories established by IUCN in 1993 following an extensive review of its earlier systems of categories. They are arranged in ascending order of degree of human use permitted in the area (IUCN, in press).

Table 2 Categories of protected areas

I . Strict Nature Reserve/Wilderness Area. Areas of land and/or sea possessing some outstanding or representative ecosystems, geological or physiological features and/or species, available primarily for scientific research and/or environmental monitoring; or large areas of unmodified or slightly modified land, and/or sea, retaining their natural character and influence. without permanent or significant habitation, which are protected and managed so as to preserve their natural.condition.

I National Park: Protected Areas Managed Mainly for Ecosystem Conservation and Recreation. Natural areas of land and/or sea, designated to (a) protect the ecological integrity of one or more ecosystems for this and future generations, (b) exclude exploitation or occupation inimical to the purposes of designation of the area and (c) provide a foundation for spiritual, scientific, educational, recreational and visitor opportunities, all of which must be environmentally and culturally compatible.

I Natural Monument: Protected Areas Managed Mainly for Conservation of Specific Features. Areas containing one, or more. specific natural or natural/cultural feature which is of outstanding or unique value because of its inherent rarity, representative or aesthetic qualities or cultural significance.

N Habitat/Species Management Area: Protected Areas Managed Mainly for Conservation Through Mangement Intervention. Areas of land and/or sea subject to active intervention for management purposes so as to ensure the maintenance of habitats and/or to meet the requirements of specific species.

V Protected Landscape/Seascape: Protected Areas Managed Mainly for Landscape/Seascape Conservation and Recreation. Areas of land, with coast and sea as appropriate, where the interaction of people and nature over time has produced an area of distinct character with significant aesthetic, cultural and/or ecological value, and often with high biological diversity. Safeguarding the integrity of this traditional interaction is vital to the protection, maintenance and evolution of such an area.

VI Managed Resource Proteced Area: Protected Areas Managed Mainly for the Sustainable Use of Natural Ecosystems. Areas containing predominantly unmodified natural systems, managed to ensure long term protection and maintenance of biological diversity, while providing at the same time a sustainable flow of natural products and services to meet community needs.

\section{Benefits of protected areas for local communities}

One of the reasons for the insufficient progress in protecting habitats and biological diversity in Asia may be a lack of appreciation of their relevance to important national priorities, especially food production. Properly designed and managed protected areas are not "set aside" from development; rather, they are allocated to protective management to support national development objectives. Far from being "living museums", protected areas can bring many benefits to local people, the nation and the entire world. Those benefits are of two general kinds, goods and services. 


\section{1 Material benefits from protectecd areas}

Establishing protected areas brings significant changes in the remote areas where most such areas are likely to be established. The people living in those areas have long depended on the natural resources that are available there. Experience, as well as logic, indicates that local communities are likely to support protected areas to the extent that such areas provide benefits to them. especially in the form of continued availability of the resources contained in the protected areas. Such resources include bamboo, firewood, construction materials, medicinal plants, timber, fish, animal skins, honey, beeswax, fibers, gums, resins, ornamentals, game meat, fodder, mushrooms, fruits, and dyes. The benefits of these are relatively clear to local people, as they have typically been harvested sustainably for hundreds - or even thousands - of years. The local people have often developed mechanisms for managing these resources and allocating the benefits among the community. In remote areas, many of these benefits are experienced directly, without passing through a market.

The benefits of resources harvested and consumed locally can be considerable. For example, in Sarawak. Malaysia a detailed field study found that wild pigs harvested by hunters had a market value of some US \$ 100 million per year (Caldecott, 1988). Other resources are commercially harvested for exchange in formal markets; their value can be assessed directly by the prices paid for them. When resources that have traditionally been harvested for consumptive use suddenly become valuable on the market, they are subject to abuse. For example, it appears that conflicts between state landmanagement policies and locally operating forest-use systems are a major cause of forest land mismanagement throughout southeast Asia (Poffenberger, 1990). Radical changes in tenure rights and lack of clarity over ownership of tree and other forest products are key factors to understanding. the speed with which Asian forests have been depleted. At the species level, it is apparent that threats to species such as giant pandas, musk deer, tigers, and rhinoceroses result from external markets, not from local demand or competition.

In terms of economic development, rural communities closest to the forests or other natural areas can benefit through the sustainable harvesting of wild species to meet local consumption needs, and almost all rural communities can gain at least some development benefit through proper management of biological resources that are consumed directly. Relatively small investments aimed at ensuring that such management systems continue to function can help avoid the much larger investments which are often required when biological resources have been so severely degraded that expensive environmental rehabilitation projects are required.

The economic benefits to local communities of areas managed for sustainable use can be considerable, without the long-term disruption caused by logging. For example, in 1982 Indonesia earned some US \$200 million in foreign exchange from non-wood forest products (Gillis, 1986). In India, non-wood forest products in a recent year provided $40 \%$ of the total net revenues accruing to the government from the forestry sector, and $63 \%$ of the forestry exports (Gupta, et al. , 1982). In comparing wood and non-wood forest resources, a tropical forest tract of 50000 ha could, with effective management, produce a self-renewing crop of wild plants and animals with a potential value of at least US $\$ 10$ million per year (i. e., about US $\$ 200$ per ha), whereas the return from commercial logging would be only a little over US $\$ 150$ per ha (Myers, 1988). Moreover, 
commercial logging uses ecologically disruptive timber-harvesting practices, whereas the harvesting of wildlife and medicinal plants can leave forest ecosystems in a productive state.

Similar results come from a study to assess market values from all commercial tress on a 1 ha tract of species-rich forest in Peruvian Amazonia (Peters, et al., 1989). That tract of forest (located on the Rio Nanay about $30 \mathrm{~km}$ southwest of the city of Iquitos) contained 275 speices of trees, with a total count of 842 trees 10 centimeters or more in diameter, and with a standing merchantable timber volume of 94 cubic meters. Some $40 \%$ of the trees in the tract were seen to have the potential for yielding renewable marketable products such as fruit, latex, or timber. Clear-cutting the 1-ha tract would give a one-time net financial return of about US $\$ 1000$, with little prospect of future earnings from other sources (this and the estimates below being expressed in 1987 US dollars). On the other hand, the fruit from the tract could provide a net income of about US $\$ 300$ per year; the latex about US $\$ 20$ per year; and the merchantable timber (logged sustainably) about US $\$ 320$ once every 20 years. Discounting these three sources of perpetual income to the present at $5 \%$ gives the tract a value of about US $\$ 7000$. Moreover, some additional sustainable revenues could be realized from the periodic harvesting of wildlife, medicinal plants, and other minor products.

\section{2 Environmental services from protected areas}

Protected areas also can provide valuable services to local communities. These include soil regeneration, nutrient cycling, pollination, recreation, provision of pure water, and maintenance of the functioning ecosystem which yields harvestable resources. Such benefits are often difficult to quantify, and even local people may take them for granted. But conserving these processes cannot be divorced from conserving the individual species that make up natural ecosystems.

Environmental services do not normally appear in national accounting systems, but they may far outweigh direct values when they are computed. These values tend to reflect the value of biological diveristy to society locally or at large rather than to individuals or corporate entities. For example, in Sabah recent studies suggest that high densities of wild birds in commercial Albizia plantations limit the abundance of caterpillars that would otherwise defoliate the tress; the birds require natural forest for nesting (Fitter, 1986), but the function the birds perform is assigned no value in either national accounting systems or in calculations of the environmental cost of clearing the forest.

One of the most important such services, especially in view of the major investments in water resource management in much of Asia, is the stabilizing of hydrological functions. Natural vegetational cover on watersheds regulates and stabilizes water run-off. Deep penetration by tree roots or other vegetation makes the soil more permeable to rainwater so that run-off is slower and more uniform than on cleared land. As a consequence, streams in forested regions continue to flow in dry weather and floods are minimized in rainy weather. It has been shown that in Malaysia the peak runoff per unit area of forested watersheds is about half that of rubber or oil palm plantations, whereas the low flows are roughly double (Daniel, et al., 1974).

Watershed protection has helped justify many valuable reserves which otherwise might not have been established, so irrigation and energy agencies have the potential to make powerful allies for protected areas that protect watersheds (McNeely, 1987). In Thailand, it has been shown that an annual expenditure for watershed protection related to the Nam Pong Reservoir of about US $\$ 1.5$ 
million would be justified in terms of benefits to the reservoir (Hufschmidt, et al., 1986). In Indonesia, the Dumoga-Bone National Park was established as the result of a loan of US\$1.2 million from the World Bank, justified on the basis of the protection the park provided to a major irrigation project in the lowlands below. The challenge is to ensure that such benefits actually reach the local communities.

Good soil protection by natural vegetational cover and litter can preserve the productive capacity of the protected area, prevent dangerous landslides, safeguard riverbanks, and prevent the destruction of fisheries by siltation. In Malaysia, the suspended stream sediment load following logging increased by $70 \%$ to $97 \%$ (Kasran 1988). Thus, protected areas can contribute significantly to the longevity of downstream reservoirs and irrigation systems. A stark example of the value of soil conservation is provided by the Royal Chitwan National Park of Nepal (Roberts, et al., 1985). Outside the park, villagers have cleared and grazed the north bank of the Rapti River (which forms the park boundary) so intensively that it is the subject of rapid erosion. Within the park, on the south bank, the protected vegetation binds the soil so that when monsoon rains swell the river it is only the north bank that is washed away. As a result, the course of the river is shifting. In a period of less than a decade roughly 100 ha was taken from villagers and added to the park by natural forces.

In conclusion, although wild products have been harvested by people in Asia for thousands of years, the increasing population and changing social and political structures of today have removed most traditional controls on how those resources are harvested. If sustainable benefits are to be provided to local communities, more effective controls may be required to ensure that wildlife populations are maintained at productive levels. The means of doing this will vary from place to place, but the foundations must be built on sound economic and ecological principles. Establishing wellmanaged protected areas may provide new approaches to resource management based on sustainable use, thereby restoring at least part of the balance that has enabled human populations to survive in rural Asia.

\section{Managing protected areas to benefit local communities}

This section suggests some of the ways that protected areas can be managed to earn the support of local people, focussing on the provision of economic incentives to the local community and on its involvement in decision making.

\section{1 Providing economic incentives to the local community}

Since experience has shown that resource exploitation is generally governed by the perceived selfinterest of individuals or groups, behavior affecting biological resources can best be changed by providing new approaches to conservation that alter the perceptions by people of their self-interest. Since self interest today is defined primarily in economic terms, conservation needs to be promoted primarily through the means of economic incentives.

Incentives can be used to divert land, capital, and labour towards conservation. They can smooth the uneven distribution of the costs and benefits of conserving biological resources, mitigate anticipated negative impacts on local people by regulations controlling exploittation, compensate people for any 
extraordinary losses suffered as a result of such controls, and reward the local people who make sacrifices for the benefit of the larger public. Incentives are clearly worthwhile when they stimulate conservation activities at a lower economic cost than that of the economic benefits received.

In the Sagarmatha National Park of Nepal (a World Natural Heritage Site), initial hostility to the park was converted into strong support through economic incentives such as employment in tourism-related activities, preferential employment as park staff, registration of land to establish tenure rights, restoration and protection of religious structures inside the park, a return of forest management to the village, and community development activities clearly linked to the park (Norbu, 1985).

The foundation of any package of incentives is community support, and such support is gained only through involvement. The following five elements are essential (McNeely, 1988):

(a) Motivation: Potential participants must be convinced that the problem being addressed by the package of incentives is a high priority for the community. If farmers are shown that the proposed protected area can help overcome present constraints, the results will be positive. This is done by making the community part of the planning process from the earliest stages, and making them the leading actors throughout the process of designing and managing the protected area;

(b) Benefits: Both the individual farmer and the larger community must clearly perceive the benefits they will derive from the protected area, either through direct profits — such as through active participation in tourism development or cash payments for benefits foregone — - or else from less direct incentives such as improved educational opportunities, transportation, or employment;

(c) Information: The community needs to be informed about the package of incentives, including its costs and benefits and any accompanying disincentives (e. g., protective legislation). The implementing agencies need to clear up any doubts and encourage the rural people to participate fully. The outcome of the promotional campaign should be a better informed rural population that participates actively in conservation activities;

(d) Viable options: The options offered to rural people need to be accessible; and within the capacity of government or private enterprise to provide. Solid financial and logistical backing must be guaranteed and any restrictions to local participation eliminated; and

(e) Skills: The rural people need to have or obtain the skills required to implement the activities stimulated by the package of incentives, which implies technical assistance and training as well as education in the broad sense.

Determining which incentives will be most useful in stimulating the desired behavior at the community level should begin with an analysis of how current governmental social and economic policies are affecting the behavior of the villagers toward biological resources. It is often useful to undertake a socioeconomic survey of the communities affected by regulations controlling the use of biological resources. Such surveys can also provide the necessary raw material for determining the types of incentives that would be required to bring about the desired changes in behavior. Information collected might include:

(a) the ethnic diversity of the communities and their social structure;

(b) the traditional location and proximity of householder and kin groups for ritual, labour-exchange, 
and other important community activities;

(c) standard indicators of socioeconimic well-being, including demographic parameters such as population and age structure as well as indicators of health and education:

(d) the pattern of economic activity, in both time and space, particularly in regard to how this affects biological resources:

(e) patterns of land tenure, land use, and access to resources;

(f) the biological resources now being used, how the resources are being harvested, the degree of awareness about controlling regulations, and possible alternative sources of income; and

(g) the importance of the biological resources, both economically (as food, raw materials, and income) and socially (their role in kin and other community relationships).

The information collected can provide protected-area managers with the necessary insights into the needs and desires of the local people, and can avoid misunderstandings and disruptions in the implementation of packages of incentives. Community-level institutions should be fully involved in the design, implementation, and interpretation of such surveys.

4. 2 Involving the local community in decision making

Increased utilization has almost always been accompanied by a reduction in biodiversity, both in agricultural ecosystems and in more natural ecosystems. In the process, local people have sometimes lost local autonomy over resources. For example, in Thailand subsidized commercial fisheries have all but wiped out artisanal fisheries (Rowchai, 1989). In Indonesia, Malaysia, the Philippines, and Thailand. logging rights have been given to concessionaires with little reference to the prior traditional ownership rights of resident people, nor of the impact of logging on them. Thus conflicts have arisen between modern and traditional forms of land and resource use, in the name of development.

For protected-area managers, detailed knowledge of the people whose lives are affected by the establishment and management of reserves is as important as information about the plant and animal species to be conserved. The cultural and socio-economic characteristics of local people —_- including the age and gender divisions of labour — form the basis for measures to promote the sustainable use of natural resources, alleviate poverty, improve the quality of human life, and create support for protected areas.

Community participation and equality, with mutual respect among cultures are essential in decision-making processes. Customary tenure systems, traditional knowledge and practices, and the role of men and women in communities, must be respected and built upon in designing and implementing conservation plans.

At the same time, community involvement does not mean opening protected areas to all comers, any more than a banker would seek customers by opening the vault. Rather, a wise protected-area manager, like a wise banker, uses the assets of a park as a base upon which to build customer satisfaction, investment, and interest. The challenge is to seek the right balance.

People can reasonably be expected to institute their own conservation measures when they are the primary decision makers and beneficiaries. Numerous examples can be cited from other parts of the world (e. g., Birckhead, et al., 1992; Stone, 1991; UNEP, 1988; Wells, et al., 1992; West. et al. , 1991). A few illustrations may be helpful. In Peru, the Reserva Comunal Tamshiyacu-Tahuayo 
covers 322500 ha and has no permanent settlements (Bodmer, et al. , 1291). It is divided into a fully protected core area and an area of subsistence use. Actions implemented by the local people to control exploitation include prohibition of the use of nets and lances in the oxbow lakes of the reserve during low water seasons, limitations on fishing technology, prohibition of commercial fisheries, and prohibition of the use of fish poisons. Fish populations in the area appear to be rebuilding and the local communities are directly benefitting from their self-imposed management programmes.

In Papua New Guinea, where about $97 \%$ of the land is in community ownership, the government has established 'wildlife management' areas where local communities voluntarily agree to certain controls on exploitation (Eaton, 1985). Each wildlife management area has a Wildlife Management Committee with representatives from local communities as well as from government resource-management agencies. These committees have instituted measures such as establishing royalties for the taking of deer, duck, and fish by outsiders; hunting restrictions such as the forbidding of all but traditional hunting methods, the use of shotguns, and the use of dogs: prohibiting the collection of crocodile eggs; fishing restrictions such as forbidding the sue of commercially manufactured nets, of hurricane lamps, and of fish poisons; and restrictions on logging. In all areas, the rules enacted tend to promote traditional practices and authority.

These examples. and numerous others that could be cited from all parts of the world, support the general point that earning the support of local communities means giving them a real stake in the success of a well-managed protected area.

\section{CONCLUSION}

Establishing an effective network of protected areas in East Asia will require a combination of: (a) incentives and disincentives; (b) economic benefits and law enforcement; (c) education and awareness; (d) employment in the protected area and employment opportunities outside; and (e) enhanced land tenure and control of new immigration (especially if the buffer zones around protected areas are targeted for specieal development assistance). The key is to find a balance among the competing demands, and this will usually require a site-specific solution.

The approach to protected area management advocated here, involving partnership with local human communities for the benefit of both the protected areas and biodiversity, faces formidable challenges. Many protected area staff believe that a cooperative approach could ultimately reduce the quality of the protected area; they believe that strong legislation supported by vigorous law enforcement is the best option for long-term conservation. And indeed, experience has shown that local people sometimes are as likely as anyone else to misuse privileges under cooperative management. Even so, given the insufficient staff and logistical support likely to be available to most protected areas in the rural parts of Asia, the "strict preservationist approach" would not only be impossible to implement, but would even be of doubtful validity on conservation grounds. The proposed conciliatory and cooperative approach may be the only viable option in the conditions of today (Ishwaran, 1992).

There should be no illusions about the severity of the problems to be faced in the coming years. The conflicts of tomorrow will be even more difficult than those of today, as resource scarcity, 
economic imbalance, population growth, expanding consumption, and continuing use of inappropriate technology form a witch's brew of challenges to protected areas, and to sustainable use of the environment as a whole. But such challenges mean that protected areas have an even more important part to play in securing a productive future for the people of Asia.

\section{REFERENCES}

Amend S. T Amend (eds.), 1992. Spacios sin habitatas ?: parques nacionales de America del Sur fareas (Without Inhabitants?: National Parks of South America). IUCN, Gland, Switzerland. 497

Batisse M, 1986. Developing and focusing the biosphere reserve concept. Nature and Resources, $22(3): 1 \sim 10$

Birckhead J. T de Lacy. L Smith (eds.), 1992. Aboriginal involvement in parks and protected areas. Australian Institute of Aboriginal and Torres Strait Islander Studies, Canberra. 390

Bodmer R, J penn. T G Fang. I Moya. 1991. Management programmes and protected areas: the case of the Reserva Comunal Tamshiyacu-Táhuayo. Peru. Parks, 1 (1):21 25

Caldecott J, 1988. Hunting and wildlife management in Sarawak. IUCN, Gland, Switzerland. 172

Daniel J G. A Kulasingham. 1974. Problems arising from large-scale forest clearing for agricultural use. Malaysian Forester, 37: 152 160

Eaton P, 1985. Tenure and taboo: customary rights and conservation in the South Pacific. 164 175. In: Third South Pacicfic National Parks and Reserves Conference: Report, Vol I. South Pacific Regional Environment Programme. Noumea, New Caledonia. 295

Fitter R, 1986. Wildlife for man: How and why we should conserve our species. Collins, London. 223

Gillis M, 1986. Non-wood forest products in Indonesia. University of North Carolina, Chapel Hill

Gomez-Pompa A. A Kaus, 1992. Taming the wilderness myth. BioScience, 42:217 279

Grumbine E. 1990. Protected biological diversity through the greater ecosystem concept. Natural Areas Journal, 10 (3) : $114 \sim 120$

Gupta T R, A Guleria, 1982. Non-wood forest products from India. New Delhi: IBH Publishing Company, 147 Hufschmidt M M, R Srivardhana, 1986. Nam Pong water resources project in Thailand. 141 162. In: Dixon J A. M M Hufschmidt (eds.), Economic valuation techniques for the environment: a case study workbood. Baltimore: Johns Hopkins University Press. 203

IIPA, 1989. Management of national parks and sanctuaries in India: A status report. New Delhi: Indian Institute of Public Administration. 297

Ishwaran N, 1992. Biodiversity, protected areas and sustainable development. Nature and Resources, 28 (1): 18 25 IUCN, 1990. 1990 United Nations List of National Parks and Protected Areas. IUCN, Gland, Switzerland. 275

Kasran B, 1988. Effect of logging on sediment yield in a hill dipterocarp forest in peninsular Malysia. Journal of Tropical Forest Science, 1 (1) :56 66

MacKinnon J, K MacKinnon, G Child. J Thorsell (eds.), 1986. Managing protected areas in the tropics. IUCN, Gland, Switzerland. 295

McNeely J A, 1987. How dams and wildlife can coexist: natural habitats, agriculture, and major water resource development projects in tropical Asia. Conservation Biology. 1:228 238

McNeely J A, 1988. Economics and biological diversity: developing and using economic incentives to conserve biological resources. IUCN. Gland. Switzerland. 236

McNeely J A (ed.). 1992. Parks for life: The proceedings of the $\mathbf{N}$ world congress on national parks and protected areas. IUCN, Gland, Switzerland. 252

$\cdot 86 \cdot$ 
McNeely J A. P S Wachtel. 1991. Soul of the tiger: searching for nature's answers in Southeast Asia. Doubleday.

New York, 390

Myers N, 1988. Tropical Forests: Much more than stocks of wood. Journal of Tropical Ecology, 4:209 221

Nabhan G P, A M Rea, K L Reichhardt, E Mellink, C F Hutchinson, 1982. Papago influences on habitat and biotic diversity: Quitovac oasis ethnoecology. Journal of Ethnobiology, 2: 124 143

Norbu L S. 1985. Management issues in Nepal's national parks. 123 127. In: McNeely J A. J W Thorsell (eds.), People and protected areas in the Hindukush-Himalaya. Kathmandu: Internaitonal Centre for Integrated Mountain Development, 250

Peters C M. A H Gentry, R O Mendeslsohn, 1989. Valuation of an Amazonian rainforest. Nature 339:655 656

Poffenberger M (ed.), 1990. Keepers of the forest: land management alternatives in Southeast Asia. West Hartford: Kumarian Press, 289

Redford Kent H, 1990. The ecologically noble savage. Orion Summer. $25 \sim 29$

Roberts J O M. B D G Johnson. 1985. "Adventure" tourism and sustainable development: experience of the tiger mountain group's operations in Nepal. $81 \sim 84$. In: McNeely J A. J W Thorsell (eds.). People and protected areas in the Hindukush-Himalaya. Kathmandu: International Centre for Integrated Mountain Development. 250

Rowchai S, 1989. Economic incentives for the conservation and use of marine fishery resources. A contribution to IUCN project on economic incentives for biological resource Conservation in Thailand (Mimeo, in Thai).

Spencer J E, 1966. Shifting cultivation in Southeastern Asia. Berkeley: University of Californai Press, 247

Stone R D. 1991. Wildlands and human needs: Reports from the field. World Wildlife Fund, Washington D. C. 151

UNEP, 1988. People parks and wildlife: Guidelines for public Participation in wildlife conservation. UNEP. Nairobi. 112

Wells M, K Brandon. 1992. People and parks: linking protected area management with local communities. International Bank for Reconstruction and Development. World Bank, Washington. 99

West P C, S R Brechin (eds.), 1991. Resident peoples and national parks: social dilemmas and strategies in international conservation. Tucson: University of Arizona Press, 443

Wharton C. 1968. Man. fire, and wild cattle in Southeast Asia. Proceedings of the Annual Tall Timers Fire Ecology Conference. $7: 107 \sim 167$

WRI, 1992. World Resources 1992 1993. New York: Oxford University Press. 385 